\title{
Interpreting the geomorphometric indices for neotectonic implications: An example of Alaknanda valley, Garhwal Himalaya, India
}

\author{
Naresh Rana ${ }^{1,3, *}$, Sunil Singh ${ }^{1}$, Y P Sundriyal ${ }^{1}$, G S Rawat $^{1}$ and Navin Juyal ${ }^{2}$ \\ ${ }^{1}$ Department of Geology, HNB Garhwal University, Srinagar Garhwal, India. \\ ${ }^{2}$ Physical Research Laboratory, Navrangpura, Ahmedabad, India. \\ ${ }^{3}$ Present address: National Centre for Seismology, New Delhi, India. \\ ${ }^{*}$ Corresponding author.e-mail: naresh_geo@yahoo.co.in
}

Tectonic process can influence the erosion and exert the first order impression on hydrographic network of an area. Geomorphometry, a mathematical analysis of the configuration of the landforms, allows quantifying the degree of landform evolution and is widely used as a measure of tectonic deformation/uplift. Alaknanda valley lies in the tectonically active Garhwal Himalaya which has experienced two disastrous large earthquakes in the last two decades. Morphometric analyses of the valley were carried out in a fluvial erosion dominated regime and the morphometric indices were derived from the ASTER $(30 \mathrm{~m} \times 30 \mathrm{~m}$ pixel) Digital Elevation Model (DEM) using Arc GIS. The results of the analyses reveal two zones of high deformation/uplift in the valley, viz., the zone of high deformation proximal to the Main Central Thrust (MCT) in the Inner Lesser Himalaya (ILH) and the second zone of moderate deformation/uplift in the Outer Lesser Himalaya (OLH), south of the Tons Thrust (TT). The high deformation in the ILH is ascribed to the focussed convergence and high precipitation; however, the causes for the moderate deformation in the OLH are yet to be established.

\section{Introduction}

Himalayan topography is the outcome of the continent-continent convergence between India and Eurasia. This arc perpendicular convergence of $\sim 5 \mathrm{~cm}$ is still active as confirmed by the recent GPS studies (e.g., Molnar 1990; Larson et al. 1999; Bilham et al. 2001; Sella et al. 2002; Banerjee and Bürgmann 2002; Jade et al. 2014 and references therein) and are adequately manifested in the topography particularly during the late Quaternary (Lavé and Avouac 2001; Pratt-Sitaula et al. 2004; Juyal et al. 2010; Ray and Srivastava 2010). The variable convergence rates across the Himalayan arc (Jade et al. 2014) have been best explained by the geometry of the detachment thrust which is shallow, seismic and gentler $\left(<15^{\circ}\right)$ below the outer and Lesser Himalaya and connected with the deeper, aseismic basement thrust through a steep plane (ramp) below the Basement Thrust Front (Seeber and Armbruster 1981). According to this model, the thrust plane is locked below $\mathrm{OH}$ and LH during the interseismic period which could be the reason for maximum strain buildup in this region which releases during the high magnitude earthquakes.

The incision rates indicate that the zone of active deformation lies at the transition of the Higher Himalaya (HH) and Lesser Himalaya (LH) (Wobus et al. 2005). This zone coincidently receives highest rainfall across the Himalayan orography as revealed in the TRMM data (Bookhagen and Burbank

Keywords. Geomorphometry; uplift; tectonics; ASTER; Alaknanda valley; Garhwal Himalaya. 
2006), as a result accelerated focussed erosion is implicated for out of sequence thrusting in Central Himalaya (Nepal) (Wobus et al. 2005). In Garhwal Himalaya, Jade et al. (2014) observed significant variability in the convergence across the Himalaya arc and have reported high convergence immediate south of MCT and extension along South Tibet Detachment System (STDS).

Alaknanda River drains through the major tectono-structural units, thus provides an opportunity to test the tectonic status of the area across the strike of Himalaya, using the geomorphometry. Tectonic processes exert first order impression on the denudation that shape the landscape and develop the hydrological network. The quantitative measurement of the landforms (geomorphometry) thus can help in identifying the areas which are undergoing differential uplift (Keller and Pinter 1996; Burbank and Anderson 2001).
This paper presents the detailed geomorphometric analysis of the fluvial landforms with the objective to ascertain the spatial variability in crustal deformation in the Alaknanda valley. We used drainage density, stream frequency, circulatory ratio, texture ratio, and elevation-relief ratio of the third order basins (Total=593) draining into Alaknanda River.

\section{Study area}

The study was undertaken between the Helang (MCT) and Devprayag Fault (DF) (Valdiya 1980) $\left(79^{\circ} 30^{\prime} \mathrm{E}, 30^{\circ} 31^{\prime} \mathrm{N}\right.$ and $\left.78^{\circ} 36^{\prime} \mathrm{E}, 30^{\circ} 08^{\prime} \mathrm{N}\right)$ (figure 1). Alaknanda River, a major tributary of the Ganga River originates from the Satopanth and Bhagirathi Kharak group of glaciers located in the Chaukhamba massif $(>6000 \mathrm{~m})$. Considerable

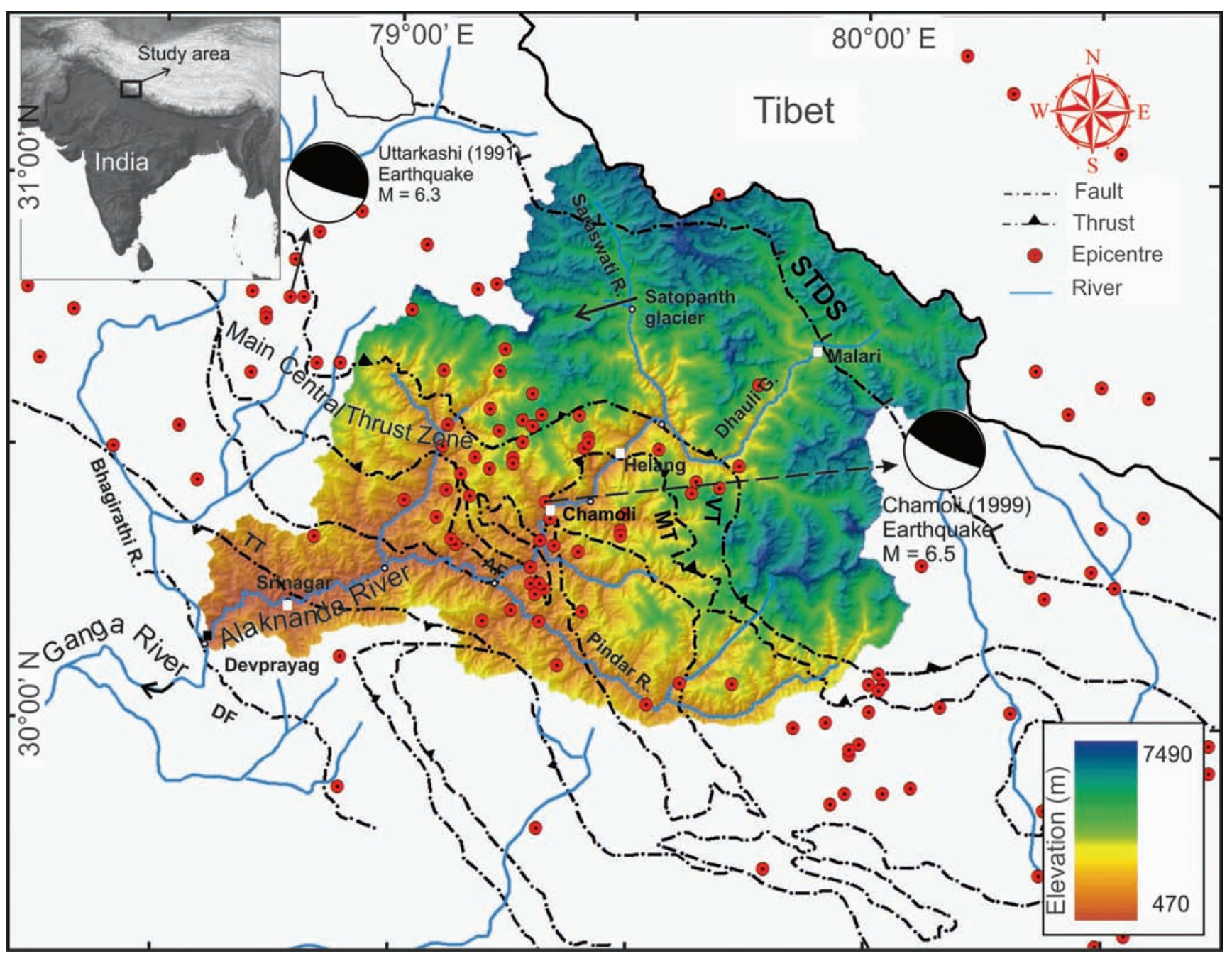

Figure 1. Location and seismo-tectonics of Alaknanda valley. STDS: South Tibet Detachment System (Trans Himadri Fault); VT: Vaikrita Thrust; MT: Munsiary Thrust; AF: Alaknanda Fault; TT: Tons Thrust; DF: Devprayag Fault. The tectonic structures adapted after Valdiya (1980). Seismic data are plotted according to the USGS (http://earthquake.usgs. gov/earthquakes/eqarchives/epic/). 
discharge into the Alaknanda River is also contributed by tributaries namely; Saraswati, Dhauli Ganga, Nandakini, Pindar and Mandakini. The river flows $\sim 230 \mathrm{~km}$ before it joins the Bhagirathi River at Devprayag at an altitude of 450 amsl. From here onwards it is called the Ganga River. The total drainage basin area of the Alaknanda River is around 10,000 $\mathrm{km}^{2}$ (Pal 1986; Srivastava et al. 2008).

Seismotectonically, the area lies in the central seismic gap (i.e., between the rupture zone of the 1905 Kangra and 1934 Bihar-Nepal earthquakes) and has been considered as potential zone for future large earthquake (Khattri 1987). The terrain in the vicinity of MCT is characterised by frequent small-to-moderate earthquakes occurring at the Basement Thrust front and is termed as Himalayan Seismic Belt (HBS). However, the large earthquake in Himalaya result in the seismically active detachment under the $\mathrm{LH}$ and $\mathrm{OH}$ (Gahlaut and Arora 2012 and references therein). In the recent time, the terrain experienced two large earthquakes, viz., the M6.3 1991, Uttarkashi and M6.5 1999, Chamoli earthquake (figure 1). These earthquakes occurred along the plane of detachment (Main Himalayan Thrust or Basement Thrust), which reactivated the local faults (Kayal 2010).

\section{Geologic, geomorphic and climate setup}

Lithologically, the Alaknanda River traverses through the Tethyan Sedimentary Sequence (TSS), Higher Himalayan Crystalline (HHC) and the Lesser Himalaya Metasedimentaries (LHM) (Heim and Gansser 1939). The above lithological units are differentiated by the STDS and the MCT (figure 1). Besides these, the AF and TT are the major tectonic structures located in the ILH and OLH respectively (figure 2). Geomorphologically, Alaknanda catchment can be divided into three major zones: the upper glaciated terrain (above 3500 masl), the middle paraglacial zone ( 2500 masl) and the lower fluvial zone (below 2500 masl). As we move upstream from Devprayag,

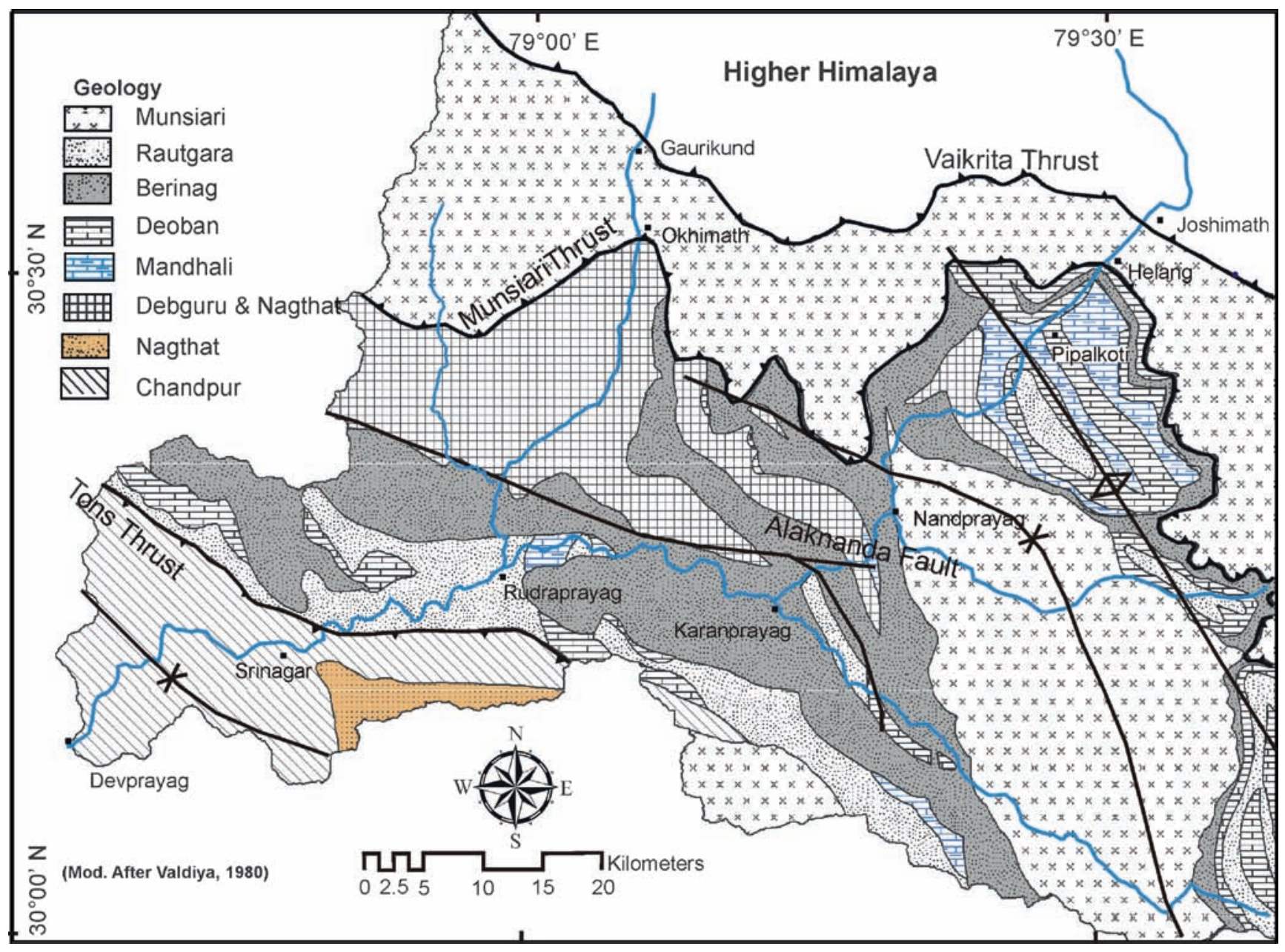

Figure 2. Geological map of Lesser Himalaya in Alaknanda valley. The lithologies and structures are adapted after Valdiya (1980). 


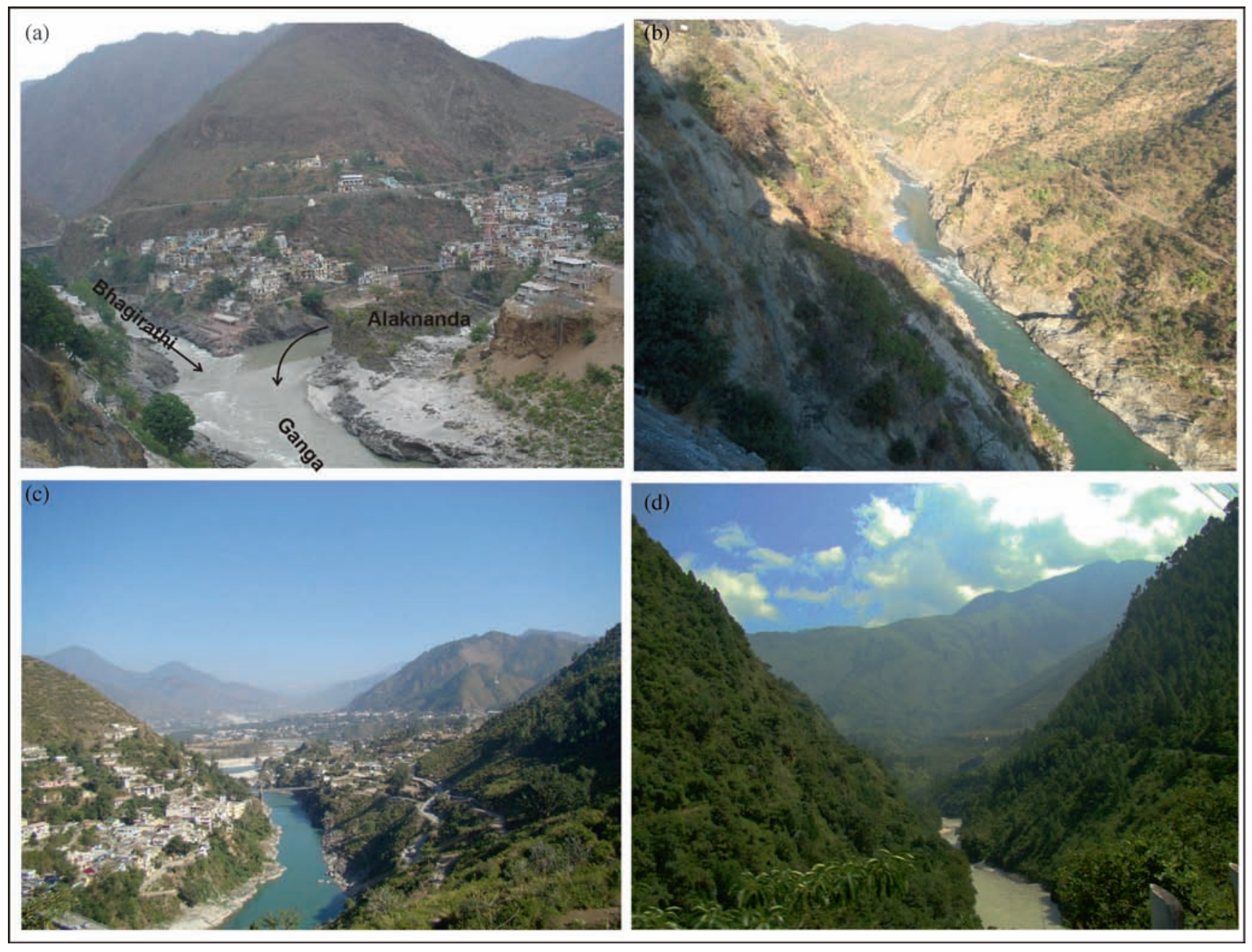

Figure 3. Variability in valley morphology. (a) Confluence of Alaknanda and Bhagirathi rivers at Devprayag. (b) River flows through narrow valley confined by the steep valley slopes. (c) Alaknanda valley is relatively wide around Srinagar and upstream till Chamoli. Note exceptionally wide segment of the river around Srinagar. (d) Typical 'V' shape valley upstream of Chamoli.

the valley slopes are characterised by the moderately developed fill and strath terraces (figure 3a). Further upstream between Devprayag and Kirtinagar, the river flows through a narrow incised valley (figure $3 b$ ) which opens up around Srinagar where spectacular fill terraces are preserved (figure 3c). Around the physiographic boundary between the ILH and the Higher Himalaya (near Chamoli), the river flows through a narrow valley with straight and steeper course (figure $3 \mathrm{~d}$ ).

The altitudinal variability which ranges from $\sim 500$ masl at Devprayag to $\sim 7800$ masl at Nandadevi, is responsible for diverse climatic conditions which ranges from subtropical to alpine type (Joshi and Kumar 2006). Besides this, rainfall is also dictated by the altitude and slope aspect. The monsoon commences towards the end of the June and terminates by the middle of September. Cloudbursts leading to torrential rain are common phenomena during the monsoon. An analysis of rainfall data shows that the average annual rainfall at different sites is about $1000-2500 \mathrm{~mm}$ of which $50-80 \%$ is received during the monsoon. The TRMM data show that the rainfall generally remain constant $(<1500 \mathrm{~mm} / \mathrm{yr})$ after Devprayag but exponentially increases $(>2500 \mathrm{~mm} / \mathrm{yr})$ near Chamoli and then gradually decline towards the north (figure 4).

\section{Method}

\subsection{Drainage basin and stream network}

Digital Elevation Model (DEM) helps in extracting the drainage network of a geographically large area (O'Callaghan and Mark 1984; Tarboton et al. 1991; Garbrecht et al. 2001). We followed the commonly used O'Callaghan and Mark's (1984) algorithms in the spatial analyst tool of ArcInfo (Arc GIS 9.3). The drainage orders are assigned according to the scheme of Strahler (1952). The third order drainage basins form the smallest unit for morphometric 


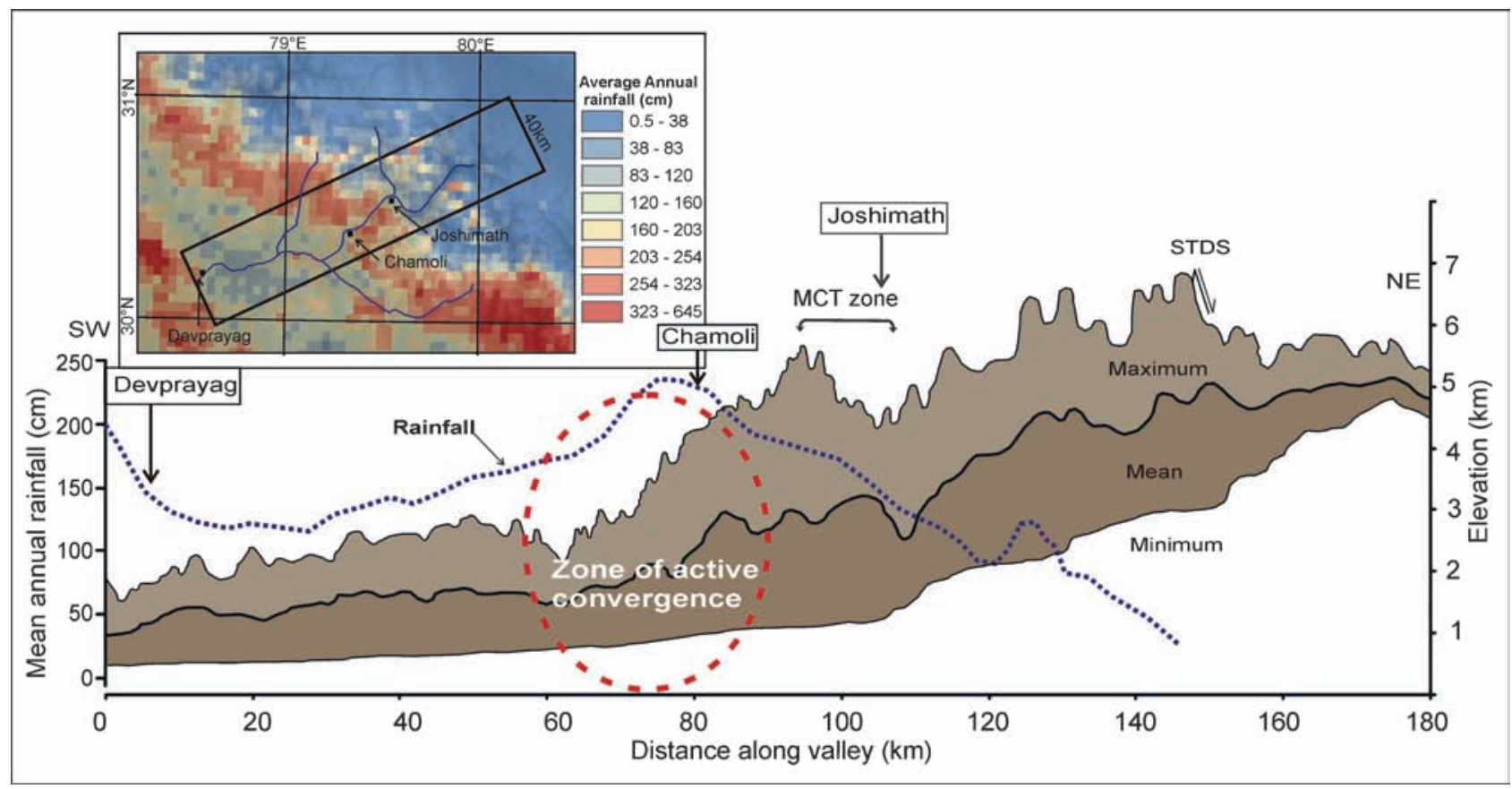

Figure 4. Topographic swath profile and rainfall variability in Alaknanda valley. Note the zone of focused rainfall coincide with the physiographic boundary between the LH and HH (Bookhagen in review) http://www.geog.ucsb.edu/ bodo/ TRMM/index.php.

analysis (Doornkamp and King 1971) and therefore, used in the present study.

The Advanced Spaceborne Thermal Emission and Reflection Radiometer (ASTER) derived DEM was processed to fill the pits or sinks, and to obtain the errorless flow directions in Flow direction grid. Flow direction grids determine the flow direction for each cell of the grid and are used as an input to calculate the flow amount. A critical (threshold) value of flow accumulation is selected after visual interpretation (stream raster). The identification of channel sources is critical for extraction of a representative drainage network from DEMs (O'Callaghan and Mark 1984; Garbrecht et al. 2001; Lin et al. 2006). We used the single map algebra in Spatial Analyst Tool of ArcInfo to test stream raster obtained with different drainage threshold values. The drainage network is extracted using a permutation and combination of the pixel values until the drainage network generated through the DEM compares reasonably well with the topographic maps. A threshold value of $10^{4} \mathrm{~m}^{2}$ mimics the drainage network of the topographic maps which is being used for subsequent geomorphometric calculations (Hamblin 1976; Cannon 1976; Bull and McFadden 1977; Ramirez-Herrera 1998).

\subsection{Stream order (u)}

Stream order is the linear property of drainage basin. It provides the first order information for the morphometric analysis. Few system of drainage ordering have been suggested (e.g., by Gravelius 1914; Horton 1932, 1945; Strahler 1952). The most common method of drainage ordering proposed by Strahler (1952) is used in the present study.

\subsection{Stream number $\left(N_{u}\right)$}

Stream number is the sum of the stream segments of each order within the drainage basin. According to Horton's (1945) law of stream number, the number of stream segments in each order forms an inverse geometric sequence, when plotted against, order. Therefore, the $N_{u}$ can be used to observe any deviation from the normal.

\subsection{Bifurcation ratio $\left(R_{b}\right)$}

Bifurcation ratio is the number of streams of any order to the number of streams of next higher order in the same drainage basin (Horton 1932; Schumm 1956). Therefore, it is the measure of the degree of branching within hydrological network. Bifurcation ratios characteristically range between 3.0 and 5.0 for basins in which the geological structures have not distorted the drainage pattern (Strahler 1964). The drainage system generally evolves by headward extension and bifurcation of first order streams (Parker 1977; Knighton 1998). Therefore, bifurcation ratio provides the quantitative estimation of stream network evolution. 


\subsection{Drainage density $\left(D_{d}\right)$}

The notation of drainage density defined by Horton $(1932,1945)$ is the basis for analysing and characterising the landscape. Although the drainage density is usually associated with the stream discharge, mean annual precipitation and sediment yield, some relationship between drainage density and rates of erosion/uplift has also been observed (Mark 1975; Montgomery and Dietrich 1989). The drainage density is the average length of streams within the basin per unit of area (Horton 1932; Tarboton et al. 1992) and can be expressed as:

$$
D_{d}=\frac{\sum(L)}{A}
$$

where $\Sigma L$ is the total length of streams included in the area $A$ (area of a third order drainage basin). Both values are expressed in units of the same system.

\subsection{Stream frequency $\left(F_{s}\right)$}

Stream frequency or drainage frequency is the total number of stream of all orders per unit area (Horton 1945). It is calculated as:

$$
F_{s}=\frac{\sum\left(N_{u}\right)}{A}
$$

where $\Sigma N_{u}$ is the total number of streams in a hydrological basin and $A$ is the basin area in square kilometers. $F_{s}$ also give the measure of drainage dissection. This is similar to drainage density which helps in ascertaining the erosional intensity processes and can be influenced by the lithological variations.

\subsection{Texture ratio $\left(R_{t}\right)$}

Texture ratio is the ratio of the total number of first order stream to the perimeter of the drainage basin (Horton 1945).

$$
R_{t}=\frac{\sum N_{u} 1}{P}
$$

where $\Sigma N_{u} 1$ is the total number of the first order stream and $P$ is the perimeter in kilometers. Textural ratio is one of the important geomorphic variables which represent the relative spacing of drainage lines. The $R_{t}$ largely depends on the infiltration capacity, lithology and relief properties of a region.

\subsection{Circulatory ratio $\left(R_{c}\right)$}

Like the elongation ratio, circulatory ratio also indicates the deviation of the drainage basin geometry from circular shape. The circulatory ratio is calculated as the ratio of the actual basin area to the area of circle having equal perimeter to the actual drainage basin (Miller 1953). The more elongated basins are suggestive of the gradual uplift (tectonics) whereas circular basins can be interpreted as their formation under overall landscape stability (Bull and McFadden 1977). This is calculated as:

$$
R_{c}=\frac{4 \pi A}{P^{2}}
$$

where $A$ is the area $\left(\mathrm{km}^{2}\right)$ and $P$ is the perimeter $(\mathrm{km})$ of the basin (which in the present case is third order basin).

\subsection{Basin hypsometry}

Hypsometric analysis is the study of the distribution of ground surface area or horizontal cross-sectional area of a landmass with respect to elevation (Strahler 1952; Keller and Pinter 1996). It is commonly used to infer the stages of geomorphic development in order to understand the influence of various forcing factors on topography such as tectonics, climate and lithology, etc. (Hurtrez et al. 1999).

The Hypsometric Curve is a normalised cumulative graphical representation showing the relative area $(a)$ of a hydrographic basin situated above a given relative altitude $(h)$. Both $\mathrm{X}$ and $\mathrm{Y}$ axes range between 0 and 1 (figure 2.3). We used ASTER DEM as a source of the data for elevation and area. A semi-automatic method using ArcInfo and the $M S$ excel software was used to generate the hypsometric curves.

The Hypsometric Integral $(H I)$ is an efficient morphometric derivate that can be used to differentiate between tectonically active and inactive areas (Keller and Pinter 1996), and is analytically expressed as percentage of drainage basin area above a basal plane of reference (Strahler 1952; Schumm 1956).

$$
H I=\int_{0}^{1} a(h) d h
$$

where $(a)$ is the surface area with in the basin above given line of elevation $(h)$.

Geometrically, this value is equal to the ratio of the volume between the land surface and a horizontal plane with $h=h_{\min }$ to the volume of a 'reference solid' bounded by the perimeter of the area and two horizontal planes with $h=h_{\min }$ and $h=h_{\max }$, respectively. The HI can also be determined graphically by measuring the area underlying the relative hypsometric curve (Strahler 1952; Mark 1975). 
Strahler (1952) correlated the value of $H I$ with the stage of landscape development. Areas characterised by $H I$ values $>0.6$ are considered to be in a 'youthful' or in equilibrium stage; values between 0.6 and 0.35 correspond to drainage basins in equilibrium, while values $<0.35$ are indicative of a transitory old stage in landscape development.

\subsection{Elevation-relief ratio (E)}

An alternative to the $H I$ is represented by the elevation-relief ratio $(E)$, which is mathematically equivalent of HI (Pike and Wilson 1971; Mark 1975; Singh et al. 2008). It is calculated as:

$$
E=\frac{E_{\text {mean }}-E_{\text {min }}}{E_{\max }-E_{\min }}
$$

where $E_{\text {mean }}$ is the weighted mean elevation of the watershed estimated from the identifiable contours of the delineated watershed; $E_{\min }$ and $E_{\max }$ are the minimum and maximum elevations (in meters) within the watershed respectively.

\section{Results}

A total of 593 third order drainage basins were analysed between the MCT (Helang) and DF (Devprayag) (figure 5a). The drainage basins area varies between 1 and $5 \mathrm{~km}^{2}$ with few basins having an area of up to $15 \mathrm{~km}^{2}$ (figure $5 \mathrm{~b}$ ). The spatial distribution of the basin size shows that the smaller basins $\left(3.5 \mathrm{~km}^{2}\right)$ are located between the MCT and AF (Chamoli) whereas, larger basins $\left(>4 \mathrm{~km}^{2}\right)$ lie in the south of the AF. Based on the average

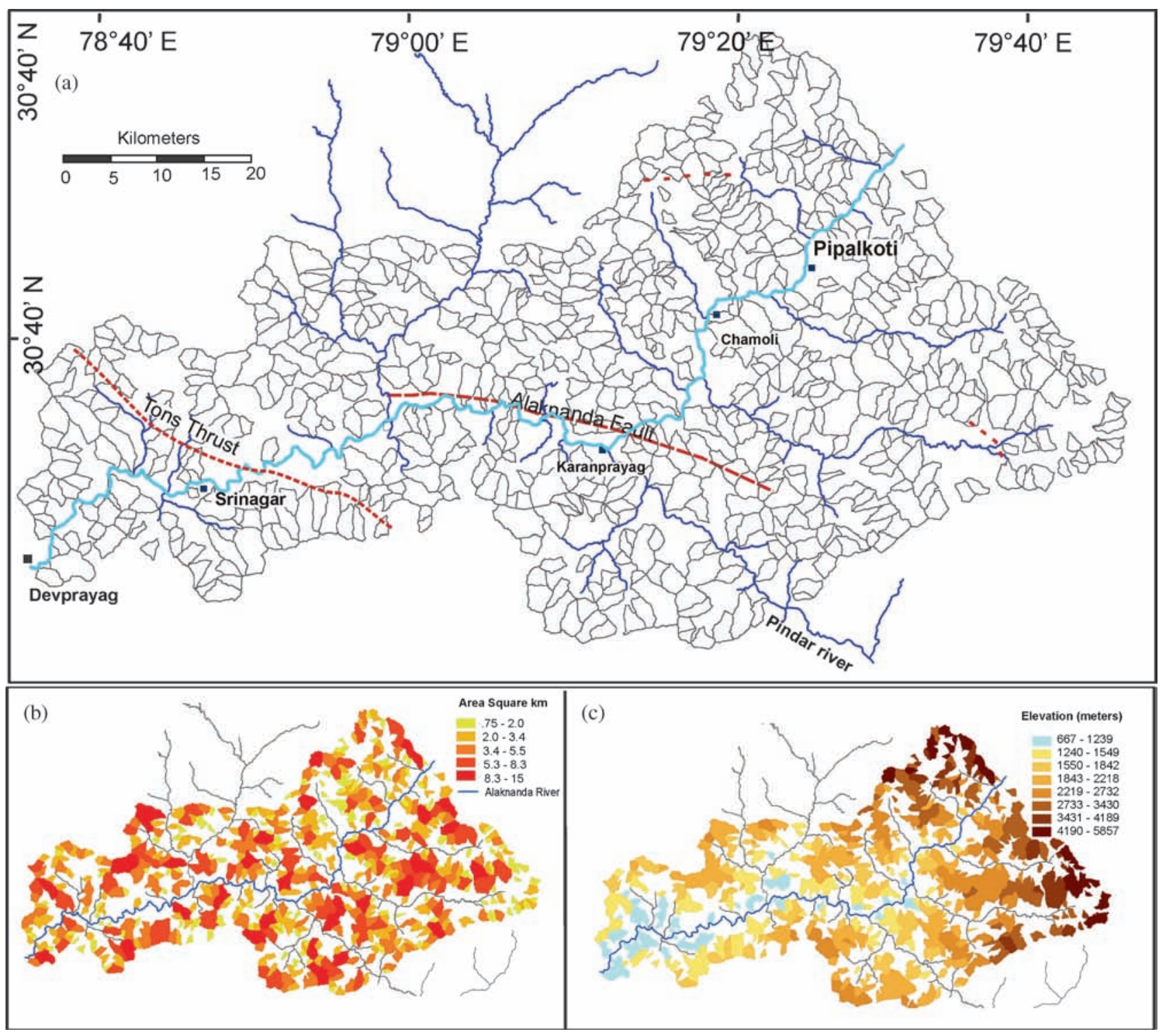

Figure 5. (a) Major drainage pattern and locations of the third order basins, (b) basin classification is based on the area and (c) mean elevation. 
pattern of distribution of morphometric variables (discussed later), the study area can be divided into three segments and are named here as zone $\mathrm{A}, \mathrm{B}$ and $\mathrm{C}$ from south to north respectively (figure 5a). Zone A lies between Devprayag and Kirtinagar (south of TT), zone B lies between Kirtinagar and Langasu (around AF) whereas zone $\mathrm{C}$ is located north of Chamoli.

\subsection{Mean elevation}

Mean elevation vary from 627 to 5857 masl (figure 5c) and broadly shows regional gradation from $\mathrm{NE}$ to SW and accords with the regional Himalayan slope. In the lower reaches (600-1500 masl), due to increase in discharge, there is a concomitant increase in the erosion which in turn is manifested in the decrease in the regional relief.

\subsection{Stream orders and bifurcation ratio $\left(R_{b}\right)$}

The stream order analysis shows that third order basins have on an average 12 first and 3 second order streams, and show positive correlation with the basin area (figures $6 \mathrm{a}$ and $7 \mathrm{a}$ ). The averaged $R_{b}$ for the study area varies from 2 to 10.65 with mean

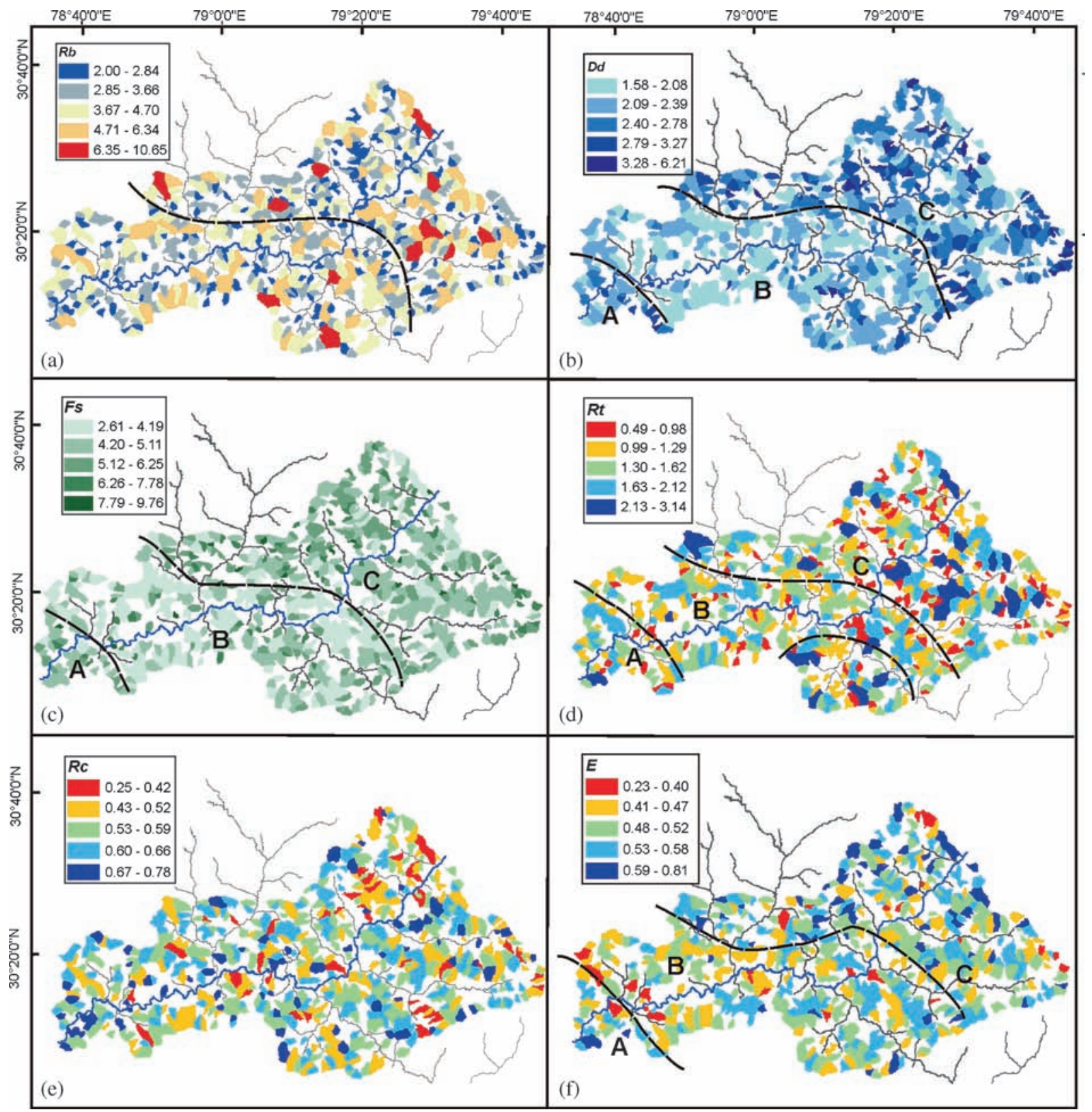

Figure 6. Classification of basins based on morphometric variables. (a) bifurcation ratio $\left(R_{b}\right)$, (b) drainage density $\left(D_{d}\right)$, $(\mathbf{c})$ stream frequency $\left(F_{s}\right),(\mathbf{d})$ texture ratio $\left(R_{t}\right),(\mathbf{e})$ circulatory ratio $\left(R_{c}\right)$ and $(\mathbf{f})$ elevation relief ratio $(E)$. Note the spatial variability in $D_{d}, R_{c}$ and $E$ clearly divide the area in three zones named here as $\mathrm{A}, \mathrm{B}$ and $\mathrm{C}$. Whereas, $R_{t}$ and $R_{b}$ also follow this trend to some extent. 

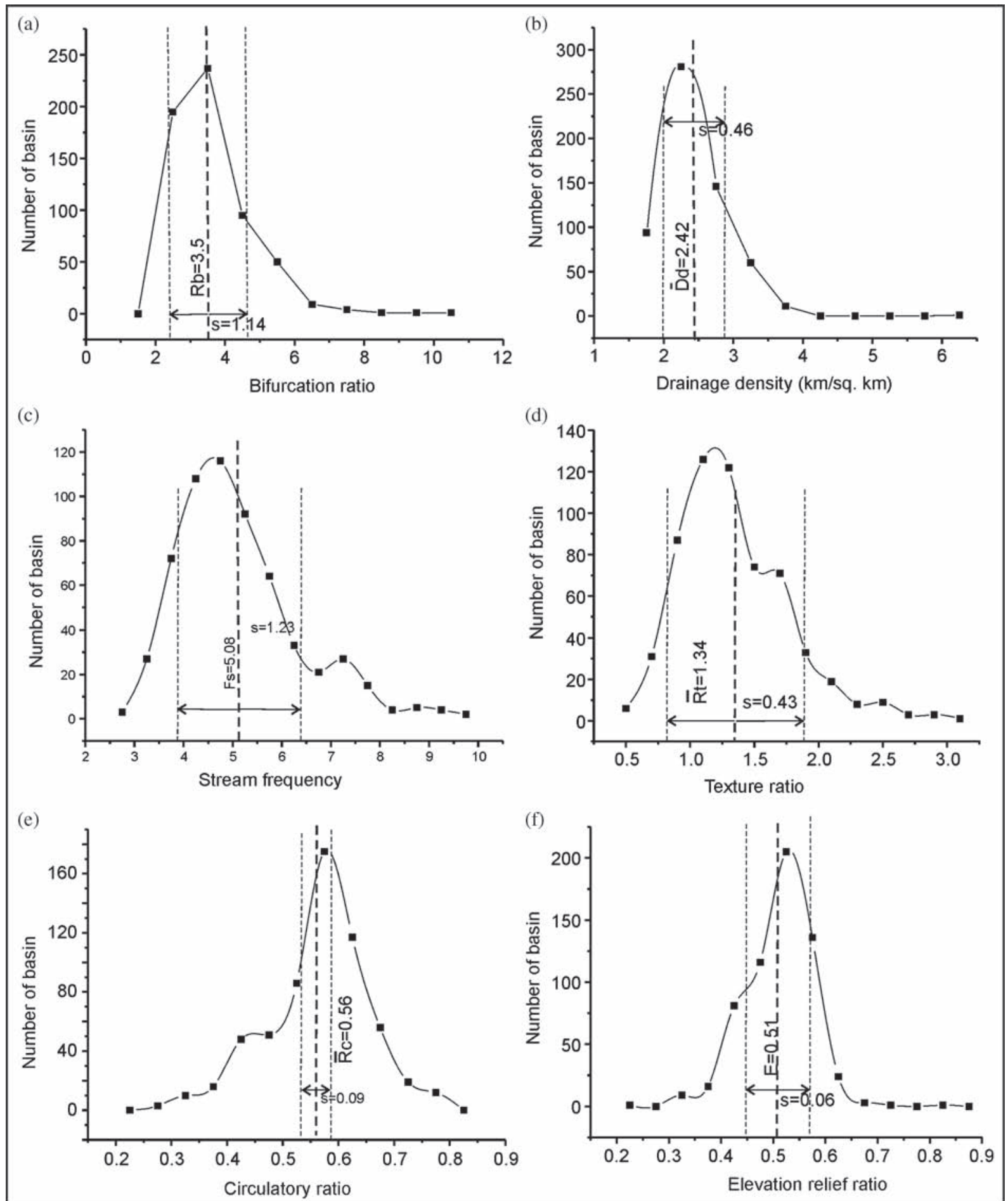

Figure 7. Frequency distribution curves of the morphometric variables.

value of 3.5. Although, the zonewise statistical mean shows insignificant variability (3.45-3.54), the spatial pattern shows that the basins with high values (6-10) are preferentially located in zone $\mathrm{C}$.

\subsection{Drainage density $\left(D_{d}\right)$}

The degree to which the basin is dissected by the channel is represented by the drainage density and often used to understand the landscape evolution in an area where climate and tectonics operate in tandem (Tarboton et al. 1992). In Alaknanda valley, the $D_{d}$ shows significant variability (1.66.2 ). The mean $D_{d}$ for the studied area is 2.42 , however, the higher $D_{d}(2.5-6.2)$ is observed in zone $\mathrm{C}$ located immediate south of the MCT whereas low $D_{d}(1.5-2.0)$ is observed in the inner LH (zone B). In addition, moderate $D_{d}$ values $(1.8-3.5)$ are 
obtained in zone A located south of TT (figures $6 \mathrm{~b}$ and $7 \mathrm{~b})$.

\subsection{Stream frequency $\left(F_{s}\right)$}

The $F_{s}$ shows a mean value of 5.1 in the study area, but varies significantly between 2.6 and 9.8 (figures $6 \mathrm{c}$ and $7 \mathrm{c}$ ). The higher values which are indicative of the high dissection (Sreedevi et al. 2009) correspond to the high mean elevation in zone C, implying that the continued uplift led to high concentration of dissected topography (tectonically active). As can be seen in figure $3(\mathrm{~d})$, the high $F_{s}$ values are obtained from valleys that are located in the north of the AF (zone $\mathrm{C}$ ) and in the south of TT (zone A). The area which lies in between (zone B) is dominated by low $F_{s}$.

\subsection{Texture ratio $\left(R_{t}\right)$}

A mean $R_{t}$ value of 1.34 was obtained for the study area (figures $6 \mathrm{~d}$ and $7 \mathrm{~d}$ ). The $R_{t}$ ranges from 0.5 to 3.1 and shows low values in zone B. The calculation is based on the first order streams which are more sensitive to uplift as compared to the higher order stream (Merritus and Vincent 1989). The statistical analysis of $R_{t}$ shows that the zone $\mathrm{C}$ has the high mean value with high variability. This may be suggestive of high terrain instability.

\subsection{Circularity ratio $\left(R_{c}\right)$}

The $R_{c}$ in the Alaknanda valley varies from 0.25 (elongated) to 0.78 (circular) (figures 6e and 7e) with a mean value of 0.56 . The extent of circularity of a basin is governed by the magnitude of uplift (Bull and McFadden 1977), and presence of elongated basins suggests high local relief and steep slope (Molin et al. 2004). Despite the relatively high mean value in zone $\mathrm{C}$, more circular basins are concentrated around AF (Gauchar-Nagrasu), and in the vicinity of TT (Srinagar). Further, the 3rd order drainages which are directly draining into the trunk river (Alaknanda), show high $R_{c}$ probably due to accelerated erosion. Geomorphic expression of accelerated erosion is manifested by the occurrence of debris flow deposits at the confluences of these drainages with the Alaknanda River.

\subsection{Elevation-relief ratio (E) and hypsometry}

The roughness of the terrain which is quantified in terms of $E$ (nearly equivalent to hypsometric integral) reflects the nature of landform evolution (Keller and Pinter 1996). The spatial distribution $E$ values shows that high $E$ values $(0.32-0.81)$ are located between Chamoli and MCT (zone C),

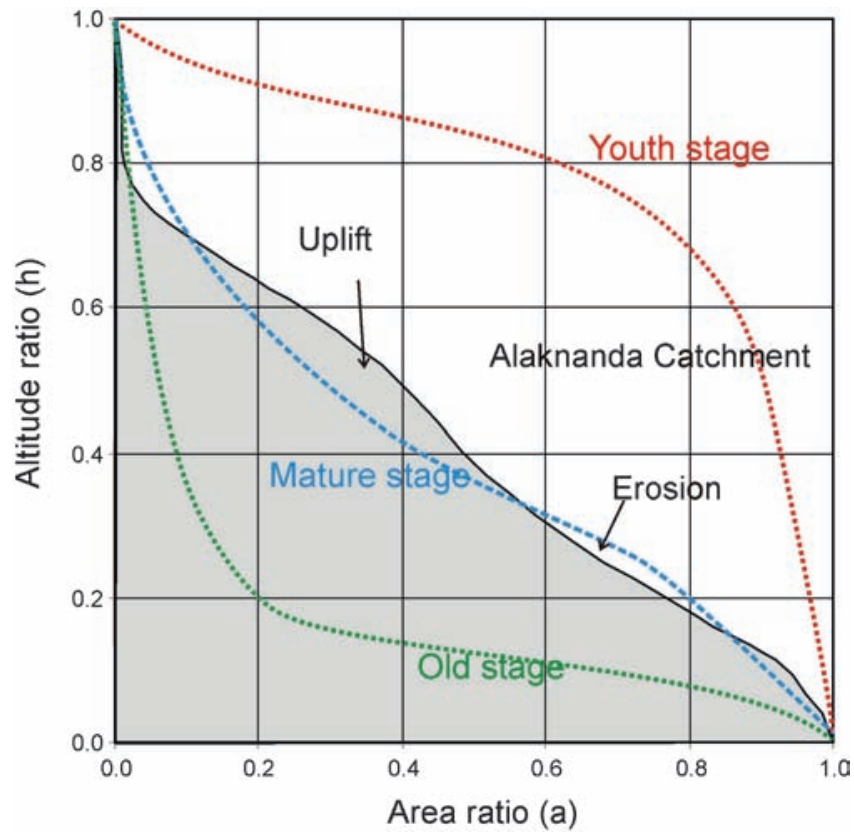

Figure 8. Hypsometric curve of the Alaknanda basin and its comparison with the hypothesized ideal curves (Keller and Pinter 1996). The curve (shaded area) shows deviation from the trend of mature stage (shown by blue dotted line).

whereas, the low $E$ values $(0.23-0.62)$ are concentrated between AF (Gauchar) and TT (Srinagar) in zone B. Further, $E$ increases in the south of TT and remain consistently high till Devprayag (0.33-0.65) (figures $6 \mathrm{f}$ and $7 \mathrm{f})$. The low $E$ value in the vicinity of NAT could be due to the presence of fissile lithology dominated by phyllite. The comparison of the basin hypsometric curves of the Alaknanda basin with the steady state curve shows a significant variance with $\sim 15 \%$ basin area lies above the curve that represent the mature stage (figure 8). This variance in terms of morphotectonics is a deviation from equilibrium state in the Alaknanda valley which can be ascribed to a transitional phase between youthful and steady state (Keller and Pinter 1996).

\subsection{Relief}

Basin relief is also an important parameter as it gives an idea about the erosion potential of the landforms (Schumm 1956). The areas exhibiting high relief are associated with high erosion (Ahnert 1970). The relief map for the entire Alaknanda drainage basin shows an average relief of $844 \mathrm{~m}$ which increases up to $2636 \mathrm{~m}$ towards the north (figure 9). In the LH, an overall low relief was observed, whereas, the $\mathrm{HH}$ is dominated by high relief which extends towards the south in the inner LH. The low relief zones in the Higher Himalaya and the Trans Himalaya could be due to high erosion caused by the glaciers (Brozovic et al. 1997). 


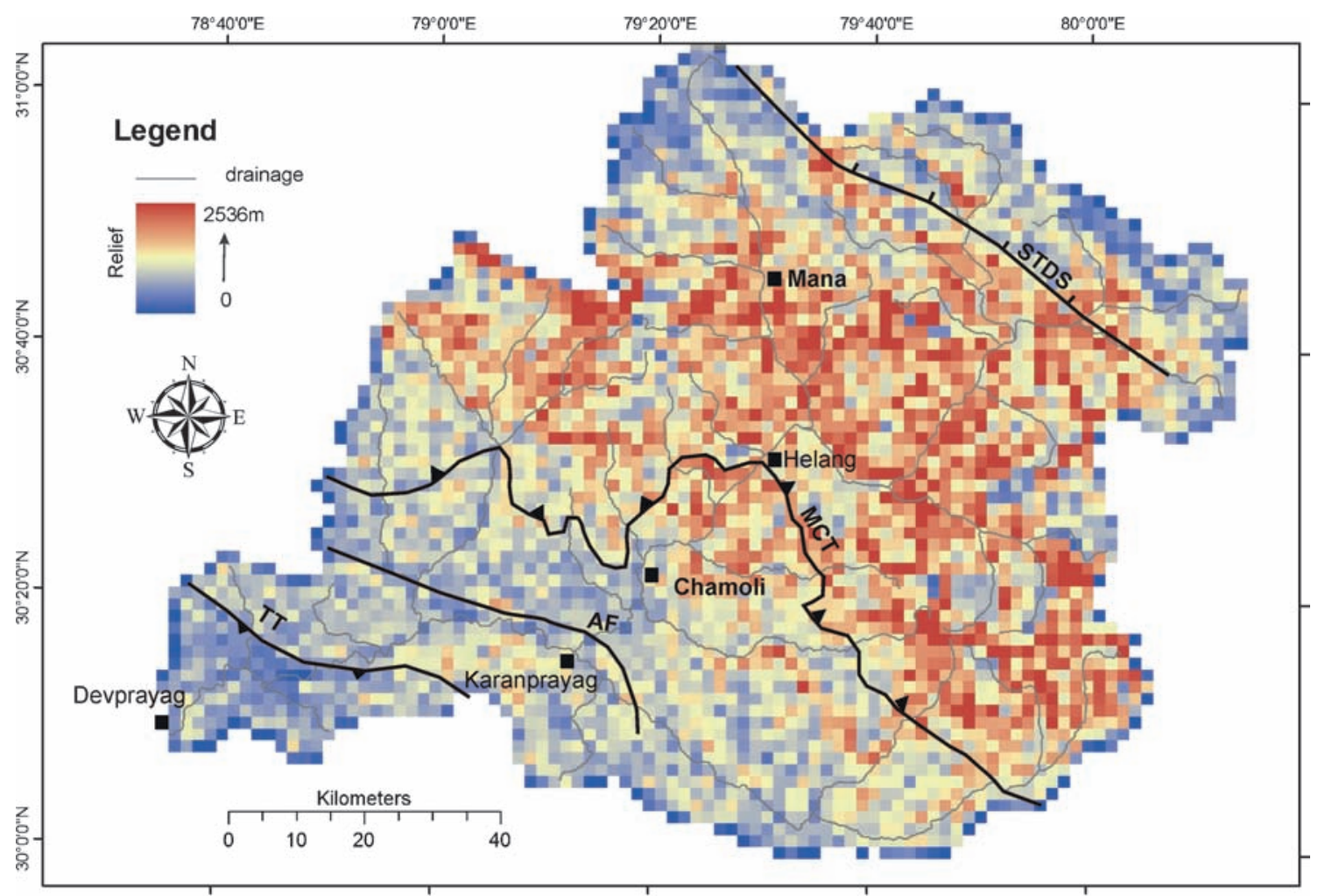

Figure 9. The basin relief (maximum elevation-minimum elevation within pixel $500 \times 500 \mathrm{~m}$ ) map shows the high relief in $\mathrm{HH}$.

\section{Discussion}

The drainage development is governed by the Horton's law of stream numbers which states that the number of streams of successively lower orders in a basin tend to form a geometric progression and increase (or decrease) according to a constant ratio (Horton 1945). Although, there are some exceptions to the above pattern of drainage evolution (Tarboton 1996), this relationship is widely used to analyse the hydrological network development caused due to tectonics and climate (Zuchiewicz 1998; Guarnieri and Pirrotta 2008; Rapisarda 2009). The drainages in Alaknanda valley exhibit an average bifurcation ratio of 3.5 but show wide variability in a segment (zone C) suggesting hydrological instability, which can be interpreted as a consequence of the continuous convergence. The stream frequency which is a representation of the drainage pattern evolution shows three distinct zones. The relatively high values are located in the vicinity of MCT (north of Chamoli - zone C) suggesting the tectonic instability. Similar trend is shown by the texture ratio and drainage density.

Hypsometric curve indicates that the Alaknanda basin is in transition stage (between youth and maturity), or alternatively, it can be suggested that the northern part is experiencing relatively high uplift compared to its southern counterpart. This is also supported by the high elevation-relief ratio in the immediate south of the MCT whereas, the low values are observed between AF (Gauchar) and TT (Srinagar). In zone A, the high elevation-relief ratio suggests relatively enhanced uplift. The high relief values between STDS and MCT indicate high uplift rate in $\mathrm{HH}$ (north of zone B), whereas, low relief values occur in the inner $\mathrm{LH}$ and suggest relatively low uplift.

Recent studies from Himalaya have demonstrated that the relief show an inverse relationship with rainfall and linear relationship with erosion (Gabet et al. 2004). However, in Alaknanda valley despite having relatively high rainfall (figure 4) and associated erosion which is morphometrically expressed in the high drainage density, stream frequency and texture ratio, a relatively high relief is observed in the terrain lying between MCT and Chamoli (zone C). This may imply that the uplift is outpacing the erosion in zone $\mathrm{C}$ which is identified as a zone of intense erosion as a consequence of climate-tectonic coupling (Wobus et al. 2005). The GPS studies also indicate focused crustal shortening in a zone located $\sim 100 \mathrm{~km}$ towards the hinterland from the MFT (Banerjee and Bürgmann 2002; Jade et al. 2014).

The morphometric indices show spatial variability throughout the area, but most of the indices show a significant change in value, which lead 


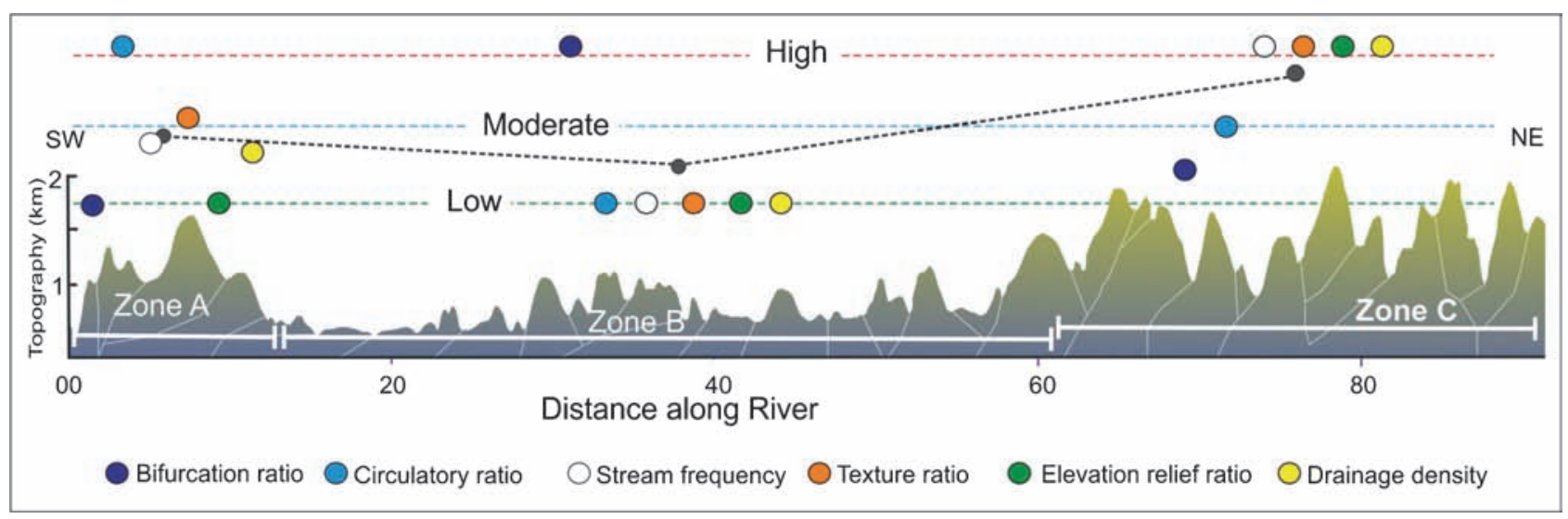

Figure 10. Variability in the geomorphic indices. The vertical position of the coloured circles show the normalised (ranging between 0 and 1) average values. The black circles connected by dotted line represent the average value for the zone.

to the distinction of three zones. They represent different degree of landform evolution and may ascribed to differential uplifts. These results are in agreement with the variability in incision rates across Himalayan arc (Lavé and Avouac 2001). Figure 10 depicts the zonal variation in geomorphometric indices. The statistical mean of geomorphometric indices are normalised for comparison and ascribed for the degree of landform evolution. The average of these values vary significantly; lowest for zone $\mathrm{B}$ and highest for zone $\mathrm{C}$. The raw values are provided as supplementary data.

\section{Conclusions}

The morphometric indices provide an overview of the landform evolution in Alaknanda valley. The spatial pattern of data infers a zone of high uplift extending south of the MCT into inner LH (figure 10). These inferences accord well with the earlier studies suggesting a zone of high uplift and deformation located along the physiographic transition between LH and HH (Seeber and Gornitz 1983; Banerjee and Bürgmann 2002; Vance et al. 2003; Wobus et al. 2005; Grandin et al. 2012; Jade et al. 2014). In addition to this, the present study identifies a zone of moderate uplift in the outer LH (zone A) whereas, a larger segment between the AF and TT exhibits subtle expression of deformations (zone B). It is worth mentioning here that rainfall pattern coincides with the zone of high uplift; therefore, the role of surface erosion cannot be ruled out.

\section{Acknowledgements}

We thank Department of Science and Technology (DST), New Delhi for providing financial assistance vide Project No., DST SR/S4/ES-416/2009(G). The constructive comments by two anonymous reviews helped to make the MS more meaningful. NR thanks Dr V K Gahalaut, Director, NCS, New Delhi for fruitful discussions. This paper forms a part of D.Phil thesis of NR.

\section{References}

Ahnert F 1970 Functional relational relationships between denudation, relief, and uplift in large mid altitude drainage basins; Am. J. Sci. 268 243-263.

Banerjee P and Bürgmann R 2002 Convergence across the northwest Himalaya from GPS measurements; Geophys. Res. Lett. 29(13), doi: 10.1029/2002GL015184.

Bilham R, Gaur V K and Molnar P 2001 Himalayan seismic hazard; Science 293 1442-1444.

Bookhagen B and Burbank D 2006 Topography relief and TRMM derived rainfall variations along the Himalaya; Geophys. Res. Lett. 33, doi: 10.1029/2006GL026037.

Brozovic N, Burbank D W and Meigs A J 1997 Climatic limits on landscape development in the northwestern Himalaya; Science 276 571-574.

Bull W B and McFadden L M 1977 Tectonic geomorphology of the north and south of the Garlock Fault, California; In: Geomorphology in arid regions (ed.) Doehring D O, Eighth Annual Geomorphology Symp. SUNY, Binghampton, pp. 127-137.

Burbank D W and Anderson R S 2001 Tectonic geomorphology (Oxford: Blackwell Science), 274p.

Cannon J P 1976 Generation of explicit parameters for a quantitative geomorphic study of the Mill Creek drainage basin; Oklahoma Geology Notes 36(1) 13-17.

Doornkamp J C and King C A M 1971 Numerical analysis in geomorphology: An introduction (London: Edward Arnold Ltd.), 372p.

Gabet E J, Pratt-Sitaula B A and Burbank W B 2004 Climatic controls on hillslope angle and relief in the Himalayas; Geology 32 629-632, doi: 10.1130/G20641.1.

Gahlaut V K and Arora B R 2012 Segmentation of seismicity along the Himalayan Arc due to structural heterogeneities in the underthrusting Indian plate and overriding Himalayan wedge; Episodes 35(4) 493-500.

Garbrecht J, Ogden F L, DeBarry P A, Maidment D R and Members ASCE 2001 GIS and distributed watershed models. I: Data coverage and sources; J. Hydrol. Eng. 6(6) $506-514$. 
Grandin R, Doin M, Bollinger L, Pinel-Puysségur B, Ducret G, Jolivet R and Sapkota S N 2012 Long-term growth of the Himalaya inferred from interseismic InSAR measurement; Geology 40(12) 1069-1062, doi: 10.1130/G33154.1.

Gravelius H 1914 Flusskunde; Goschen'sche Verlagshandlung, Berlin.

Guarnieri P and Pirrotta C 2008 The response of drainage basins to the late Quaternary tectonics in the Sicilian side of the Messina Strait (NE Sicily); Geomorphology 95 260-273.

Hamblin W K 1976 Patterns of displacement along the Wasatch Fault; Geology 4 619-622.

Heim A and Gansser A 1939 Central Himalaya, Geological observations of the Swiss Expedition, 1936; Mem. Soc. Halv. Nat. 73(1).

Horton R E 1932 Drainage basin characteristic; Trans. Amer. Geophys. Union 13 350-361.

Horton R E 1945 Erosional development of streams and their drainage basins; In: Hydrophysical approach to quantitative morphology; Bull. Geol. Soc. Am. 56 275-370.

Hurtrez J E, Sol C and Lucazeau F 1999 Effect of drainage area on Hypsometry an analysis of small-scale drainage basins in the Siwalik hills (central Nepal); Earth Surface Process and Landforms 24 799-808.

Jade S, Mukul M, Gaur V K, Kumar K, Shrungeshwar T S, Satyal G S, Dumka R K, Jagannathan S, Ananda M B, Kumar P D and Banerjee S 2014 Contemporary deformation in the Kashmir-Himachal, Garhwal and Kumaon Himalaya: Significant insights from 19952008 GPS time series; J. Geodesy 88(6) 539-557, doi: 10.1007/s00190-014-0702-3.

Joshi V and Kumar K 2006 Extreme rainfall events and associated natural hazards in Alaknanda valley, Indian Himalayan region; J. Mountain Sci. 3(3) 228-236.

Juyal N, Sundriyal Y P, Rana N and Chaudhary Shipra Singhvi A K 2010 Late Quaternary fluvial aggradation and incision in the monsoon dominated Alaknanda valley, central Himalaya, Uttarakhand, India; J. Quat. Sci. 25(8) 1293-1304.

Kayal J R 2010 Himalayan tectonic model and the great earthquakes: An appraisal; Geomatics, Natural Hazards and Risk 1(1) 51-67.

Keller E A and Pinter N 1996 Active tectonics: Earthquake, uplift and landscape; Prentice Hall, 362p.

Khattri K N 1987 Great earthquakes, seismicity gaps and potential for earthquake disaster along the Himalaya plate boundary; Tectonophys. 138 79-92.

Knighton D 1998 Fluvial forms and processes: A new perspective; Arnold, London.

Larson K, Burgmann R, Bilham R and Freymueller J T 1999 Kinematics of the India-Eurasia collision zone from GPS measurements; J. Geophys. Res. 104 1077-1093.

Lavé J and Avouac J P 2001 Fluvial incision and tectonic uplift across the Himalaya of central Nepal; J. Geophys. Res. 106 26,561-26,591.

Lin W T, Chou W C, Lin C Y, Huang P H and Tsai J 2006 Automated suitable drainage network extraction from digital elevation models in Taiwan's upstream watersheds; Hydrol. Process. 20(2) 289-306.

Mark D V 1975 Geomorphometric parameters: A review and evaluation; Geogr. Ann. Ser. A, Phys. Geogr. 57(3/4) $165-177$.

Merritus D and Vincent K R 1989 Geomorphic response of coastal streams to low, intermediate and high rates of uplift, Mendocino triple junction region, northern California; Geol. Soc. Am. 101 1373-1388.

Miller V C 1953 A quantitative geomorphic study of drainage basin characteristic in the Clinch Mountain area, Varginia and Tennessee, Project NR 389-042. Rept. 3,
Columbia University, Dept. of Geology, ONR, Geography Branch, New York.

Molin P, Pazzaglia F J and Dramis F 2004 Geomorphic expression of active tectonics in a rapidly-deforming forearc, Sila massif, Calabria, southern Italy; Am. J. Sci. 304 559-589.

Molnar P 1990 A review of the seismicity and rate of the active underthrusting and deformation at the Himalaya; J. Himalayan Geol. 1 131-154.

Montgomery D R and Dietrich W E 1989 Source areas, drainage density, and channel initiation; Water Resour. Res. 25 1907-1918.

O'Callaghan J F and Mark D M 1984 The extraction of drainage networks from digital elevation data; Computer Graphics and Image Processing 28 323-344.

Pal S K 1986 Geomorphology of river terraces along Alaknanda Valley, Garhwal Himalaya; BR Publishing Corporation, Delhi, $158 \mathrm{p}$.

Parker R S 1977 Experimental study of drainage basin evolution and its hydrologic implications; Colorado State University, Colorado, Hydrology papers 90.

Pike R J and Wilson S E 1971 Elevation-relief ratio, hypsometric integral and geomorphic area-altitude analysis; Geol. Soc. Am. Bull. 82 1079-1084.

Pratt-Sitaula B, Burbank D W, Heimsath A and Ojha T 2004 Landscape disequilibrium on 1000-10,000 year scales Marsyandi River, Nepal, Central Himalaya; Geomorphology 58 223-241.

Ramirez-Herrera M T 1998 Geomorphic assessment of the active tectonics in the Acambay graben, Mexican volcanic belt; Earth Surface Process and Landform 23 317-332.

Rapisarda F 2009 Morphometric and landsliding analyses in chain domain: The Roccella basin, NE Sicily, Italy; Environ Geol. 58 1407-1417, doi: 10.1007/s00254-008-1643-z.

Ray Y and Srivastava P 2010 Widespread aggradation in the mountainous catchment of the AlaknandaGanga River System: Timescales and implications to Hinterland-foreland relationships; Quat. Sci. Rev. 29 (17-18) 2238-2260.

Schumm S A 1956 Evolution of drainage systems and slopes in badlands at Perth Amoy, New Jersey; Geol. Soc. Am. Bull. 67 597-646, doi: 10.1130/0016-7606(1956)67[597: EODSAS]2.0.CO;2.

Seeber L and Armbruster J 1981 Great detachment earthquakes along the Himalayan Arc and long-term forecasting; In: Earthquake prediction: An international review, (eds) D W Simpson and P G Richards, Maurice Ewing Ser., AGU, Washington, D.C. 4 259-277.

Seeber L and Gornitz V 1983 River profiles along the Himalayan arc as indicators of active tectonics; Tectonophys. 92 335-367.

Sella G F, Dixon T H and Mao A 2002 REVEL: A model for recent plate velocities from space geodesy; J. Geophys. Res. 107, doi: 10.1029/2000JB000033, ISSN: 01480227 .

Singh O, Sarangi A and Sharma M C 2008 Hypsometric integral estimation methods and its relevance on erosion status of northwestern Lesser Himalayan watersheds; Water Resour. Manag. 22 1545-1560.

Sreedevi P D, Owais S, Khan H H and Ahmed S 2009 Morphometric analysis of a watershed of south India using SRTM data and GIS; J. Geol. Soc. India 73 $543-552$.

Srivastava P, Tripathi J K, Islam R and Jaiswal M K 2008 Fashion and phases of late Pleistocene aggradation and incision in the Alaknanda River Valley, western Himalaya, India; Quat. Res. 70 68-80. 
Strahler A N 1952 Hypsometric (area-altitude) analysis of erosional topography; Geol. Soc. Am. Bull. 63 1117-1142.

Strahler A N 1964 Quantitative geomorphology of drainage basins and channel network; In: Handbook of Applied Hydrology; McGraw Hill Book Company, New York, pp. 4-11.

Tarboton D G 1996 Fractal river networks, Horton's laws and Tokunaga cyclicity; J. Hydrol. 187 105-117.

Tarboton D G, Bras R L and Rodriguez-Iturbe 1991 On the extraction of the channel network from the digital elevation data; Hydrol. Process. 5 81-100.

Tarboton D G, Bras R L and Rodriguez-Iturbe 1992 A physical basis for drainage density; Geomorphology 5 59-76.
Valdiya K S 1980 Geology of Kumaon Lesser Himalaya, Wadia Institute of Himalayan Geology, Publication, Dehradun, p. 291.

Vance D, Bickle M, Iby-Ochs S and Kubik P W 2003 Erosion and exhumation in the Himalaya from cosmogenic isotope inventories of river sediments; Earth Planet. Sci. Lett. 206 273-288.

Wobus C, Heimsath A, Whipple K and Hodges K 2005 Active out-of-sequence thrust faulting in the Central Nepalese Himalaya; Nature 434 1008-1011.

Zuchiewicz W 1998 Quaternary tectonics of the Outer West Carpathians, Poland; Tectonophys. 297 121-132.

MS received 30 September 2015; revised 18 January 2016; accepted 1 February 2016

Corresponding editor: N V CHALAPATHI RAO 